\title{
New Quaternary Ammonium Salts Derived from Cardanol and their Use as Phase Transfer Catalyst
}

\author{
Isa G. J. de Avellar, Kênia Godoy and Gouvan C. de Magalhães*
}

\author{
Departamento de Química, Universidade de Brasília, 70.910-900 Brasília, DF, Brazil
}

\begin{abstract}
O cardanol, obtido a partir do líquido da castanha de caju (LCC) produzido no tratamento industrial da castanha de caju pela indústria extrativa brasileira, foi o material de partida para a síntese de sais de amônio quaternário. Compostos nitrogenados quaternários de alto peso molecular têm sido frequentemente usados como desinfetantes, germicidas e agentes sanitários, principalmente em indústria de alimentos e de limpeza. Três sais produzidos foram usados como catalisadores de transferência de fase em reações de oxidação e alquilação. Os rendimentos das reações foram próximos ou superiores aos das reações catalisadas por Aliquat ${ }^{\circledR}$.
\end{abstract}

Cardanol obtained from cashew nut shell liquid, a side product of the Brazilian industry, was the starting material for the synthesis of three new quaternary ammonium salts. High molecular weight quaternary nitrogen compounds generally possess high bactericidal activity. This report also presents the results of an investigation of the effectiveness of the new compounds as phase transfer catalysts in oxidation and alkylation reactions, whose yields were comparable to and some even greater than those obtained using the commercial catalyst Aliquat ${ }^{\circledR}$.

Keywords: cashew nut shell liquid, cardanol, quaternary ammonium salt, phase transfer catalyst.

\section{Introduction}

Cashew nut shell liquid (CNSL) is obtained as a byproduct in the production of cashew kernels. With an increasing production of raw cashew nuts, Brazil is also one of the leading world producers of CNSL1 1 . Commercial CNSL is chiefly cardanol (1) ${ }^{2}$, a mixture of 3-alkylphenols (Figure 1) mainly produced by decarboxylation of anarcadic acid (2), the primary constituent of the original oil, after exposure to high temperatures of the industrial treatment of the raw nut. Anacardic acid (2), a mixture of 2-carboxy3-alkylphenols, is the main component of the cold pressed or solvent extracted CNSL.

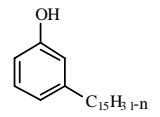

1
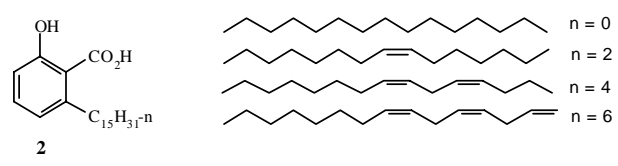

Chemicals derived from CNSL find demand in coating, photographic, polymer and surfactant markets. Our group has been developing a continuing effort on the synthetic transformation of the CNSL constituents into new substances with potential applications ${ }^{3}$. High molecular weight quaternary nitrogen compounds are very stable, soluble in water, odourless and generally possess high bactericidal activity and act as surface active agents. These properties have made them particularly attractive as germicides, disinfectants and sanitizing agents, especially in food and dairy industries. The importance of long alkyl chain and quaternary nitrogen atom as fundamental units of structure for the activity of quaternary nitrogen compounds was established as early as 1930 by Domagk ${ }^{4}$. CNSL has been used previously to prepare quaternary ammonium salts, the aim of the investigation then was to prepare water soluble compounds to be tested as germicides 5 . We report an entirely different approach, in which the quaternary ammonium cation is placed at the end of the aliphatic chain, enhancing the lipophilic character of the resulting quaternary salts, which is a requirement for a substance to function as a phase transfer catalyst.

In this work, three new quaternary ammonium salts were synthesized from cardanol for use as phase transfer catalysts. Heterogeneous reactions were tested, such as oxidation with $\mathrm{KMnO}_{4} 6$, oxidation with $\mathrm{NaClO}^{7}$ and in Williamson ether synthesis ${ }^{8}$. The yields obtained are comparable to, and in some cases surpass, those obtained using the commercial product Aliquat ${ }^{\circledR}$. 


\section{Results and Discussion}

The starting material, commercial CNSL (1), was initially distilled under reduced pressure and then treated with dimethyl sulfate $^{9}$ (Scheme 1). Distillation of the methylated material under reduced pressure and subsequent chromatography on neutral alumina gave methylcardanol (3) in $70 \%$ yield. Ozonolysis 10 of mixture 3 in dichloromethane and $\mathrm{MeOH}(4: 1)$ at $-78^{\circ} \mathrm{C}$, followed by treatment with $\mathrm{KI}$ and acetic acid afforded the desired aldehyde (4) (50\% yield). Treating 4 with hidroxylamine hydrochloride and sodium acetate 11 under reflux in ethanol gave oxime 5 in excellent yield (97\%). Hydrogenation 12 of oxime 5 over $\mathrm{PtO}_{2}$ in presence of small amounts of chloroform yielded the amine hydrochloride 6 ( $80 \%$ yield). The primary amine hydrochloride 6 was treated with methyl iodide and sodium bicarbonate 13 in refluxing methanol to give the quaternary ammonium salt 7 in $92 \%$ yield. Compound 8 was obtained in $83 \%$ yield, after quaternization of amine hydrochloride 6 with ethyl iodide and sodium bicarbonate. Under analogous conditions compound 9 was prepared in $93 \%$ yield from 6 and propyl iodide.

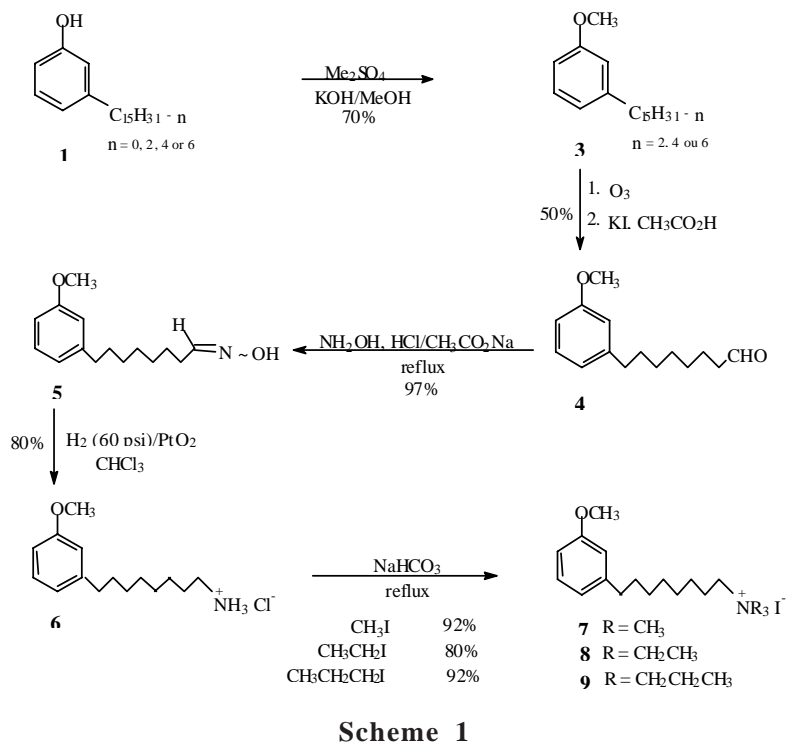

Compounds 7, 8 and 9 were then tested in three different liquid-liquid phase transfer processes: oxidation of ciscyclooctene (10) with aqueous basic $\mathrm{KMnO}_{4}$ to generate the carboxilic acid (11) (Scheme 2), oxidation of benzylic alcohol (12) to the benzaldehyde (13) with hypochlorite (Scheme 3), and the Williamson synthesis of ether 15 from benzyl alcohol (12) and excess benzyl chloride (14) in 50\% aqueous sodium hydroxide (Scheme 4).

The yields, outlined in Table 1, are comparable to those

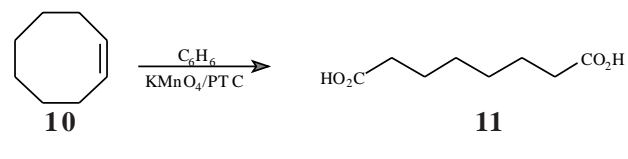

Scheme 2

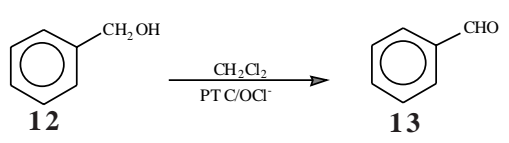

Scheme 3

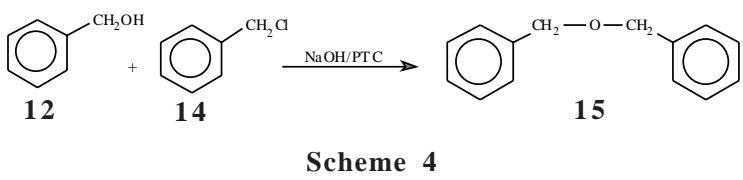

obtained when using Aliquat ${ }^{\circledR}$ as catalyst in the same reactions. Interestingly, results achieved with the new catalysts in the Williamson ether synthesis (Scheme 4) were consistently better than the yield obtained with the commercial product.

Table 1. Isolated product yields (\%) of phase transfer catalyzed reactions from schemes 2,3 and 4 .

\begin{tabular}{lcccc}
\hline \multirow{2}{*}{ Reaction } & \multicolumn{5}{c}{ Phase } & Transfer Catalyst \\
& $\mathbf{7}$ & $\mathbf{8}$ & $\mathbf{9}$ & Aliquat $^{\circledR}$ \\
\hline $\mathrm{KMnO}_{4}$ oxidation & 76 & 74 & 60 & 64 \\
$\mathrm{NaClO}$ oxidation & 67 & 27 & 26 & 49 \\
Williamson ether synthesis & 76 & 98 & 84 & 60 \\
\hline
\end{tabular}

\section{Experimental}

1H-NMR (90 MHz) were recorded on a Varian Associates T-90 spectrometer, ${ }^{1} \mathrm{H}-\mathrm{NMR}(200 \mathrm{MHz})$ and ${ }^{13} \mathrm{C}-\mathrm{NMR}(50.3$ $\mathrm{MHz}$ ) were recorded on a Bruker spectrometer and the internal references were $\left(\mathrm{CH}_{3}\right)_{4} \mathrm{Si}(\mathrm{d} 0.00)$ and $\mathrm{CDCl}_{3}(\mathrm{~d} 77.00)$, respectively. Infrared (IR) spectra were recorded on either a Perkin-Elmer 283-B or a Nicolet 2DX-FT spectrometers. Ozonolysis was performed on a Welsbach apparatus. Hydrogenations were carried out on a 3910-Parr instrument. High resolution mass spectromety data were obtained from a matrix-assisted laser desorption ionization time of flight (MALDI-TOF) Voyager-DE STR Bioworkstation spectrometer (PerSeptive Biosystems) using ferulic acid matrix. Melting points were determined on a Kofler apparatus and are uncorrected. Reactions requiring anhydrous conditions were carried out under nitrogen or argon atmosphere, using oven dried glassware. Solvents were purified by standard methodology. Light petroleum refers to the fraction with b.p. $40-60^{\circ} \mathrm{C}$. 


\section{Cardanol (1)}

Commercial CNSL, $50 \mathrm{~g}$, was distilled under reduced pressure $(1 \mathrm{mmHg})$. The pale yellow fraction collected at 206- $208^{\circ} \mathrm{C}$ corresponds to cardanol 1 (33.1 g), displaying identical spectral data with those in the literature ${ }^{14}$.

\section{Methylcardanol(3)}

Cardanol 1 (18.7 g, $62 \mathrm{mmol})$ was added to a stirred solution of $\mathrm{KOH}(5.3 \mathrm{~g})$ in methanol $(22 \mathrm{~mL})$. To the cold solution, $9.0 \mathrm{~mL}$ of dimethyl sulfate was slowly added. When the addition was completed, the ice-bath was removed and the mixture was heated to $60^{\circ} \mathrm{C}$ for $1 \mathrm{~h}$, then allowed to cool to room temperature and stirred for further $2 \mathrm{~h}$. The reaction mixture was filtered and the inorganic residue washed with light petroleum. The combined washings and filtrate were then concentrated under reduce pressure, washed with $30 \mathrm{~mL}$ of $10 \%$ aqueous potassium hydroxide solution and with several portions of distilled water. Fresh light petroleum was added and the organic extract dried over anhydrous $\mathrm{Na}_{2} \mathrm{SO}_{4}$. After filtration and evaporation of the solvent, the crude methylcardanol was distilled at $180-185^{\circ}(1 \mathrm{mmHg})$ to give $16.8 \mathrm{~g}$ of a pale yellow oil. Further purification by chromatography on neutral alumina (elution with hexane) afforded $13.6 \mathrm{~g} \mathrm{(} 44 \mathrm{mmol}$, $70 \%$ ) of methylcardanol3 as an oil: IR (film) $v\left(\mathrm{~cm}^{-1}\right): 1630$, 1604, 1588, 1498, 1261; ${ }^{1} \mathrm{HNMR}\left(\mathrm{CCl}_{4}, 90 \mathrm{MHz}\right) \delta: 0.9$ (t, 1.1 $\left.\mathrm{H}, \mathrm{CH}_{3}\right), 1.4\left(\mathrm{br}, 7.5 \mathrm{H}, \mathrm{CH}_{2}\right), 2.1\left(\mathrm{br}, 2.6 \mathrm{H}, \mathrm{CH}_{2}-\mathrm{C}=\right), 2.6(\mathrm{t}, 2$ $\mathrm{H}, \mathrm{CH}_{2}$-Ar), 2.8 (br, $\left.2.5 \mathrm{H},=\mathrm{C}-\mathrm{CH}_{2}-\mathrm{C}=\right), 3.8\left(\mathrm{~s}, 3 \mathrm{H}, \mathrm{CH}_{3} \mathrm{O}\right)$, $5.4(\mathrm{~m}, 4.5 \mathrm{H}, \mathrm{CH}=)$, 6.7-7.2 (m, 4 H, HAr).

\section{8-(3-Methoxy)-phenyl-1-(n)-octanaldehyde (4)}

Methylcardanol3 (2.37 g, 7.6 mmol) was submitted to ozonolysis in two portions: the first portion $(1.21 \mathrm{~g}, \sim 3.9$ $\mathrm{mmol})$ was dissolved in methanol-dichloromethane (1:4, 50 $\mathrm{mL}$ ), cooled to $-78^{\circ} \mathrm{C}$ and ozone was bubbled into the solution until all the starting reagent was consumed, as indicated by TLC. To the cooled reaction mixture, $\mathrm{KI}(0.8 \mathrm{~g})$ and acetic acid $(5.0 \mathrm{~mL})$ were added. The temperature was raised to room temperature, and the mixture stirred for $1 \mathrm{~h}$ and then washed in sequence with a $10 \%$ of sodium thiosulfate solution, until all iodine was consumed, distilled water, $5 \%$ solution of sodium bicarbonate and again with distilled water. The organic extract was allowed to dry over anhydrous $\mathrm{Na}_{2} \mathrm{SO}_{4}$. The second portion of $\mathbf{3}$ (1.16 g, 3.7 $\mathrm{mmol}$ ) received identical treatment. The organic extracts of the two ozonolyses were then combined, filtered, and concentrated under reduced pressure. The residue was submitted to chromatography on $60 \mathrm{~g}$ of neutral alumina with $300 \mathrm{~mL}$ of hexane, and $350 \mathrm{~mL}$ of $5 \%$ ethyl acetate in hexane to afford $0.89 \mathrm{~g} \mathrm{(50 \% )} \mathrm{of} \mathrm{aldehyde} 4$ as a colorless oil: IR (film) $v\left(\mathrm{~cm}^{-1}\right): 2719,1724,1603,1587,1489,1261 ;{ }^{1} \mathrm{H}$ $\mathrm{NMR}\left(\mathrm{CCl}_{4}, 90 \mathrm{MHz}\right) \delta: 1.3-1.6\left(\mathrm{~m}, 10 \mathrm{H}, \mathrm{CH}_{2}\right), 2.3(\mathrm{t}, 2 \mathrm{H}$, $\left.\mathrm{CH}_{2} \mathrm{CO}\right), 2.5$ (t, 2 $\left.\mathrm{H}, \mathrm{CH}_{2} \mathrm{Ar}\right), 3.7$ (s, 3H, $\left.\mathrm{CH}_{3} \mathrm{O}\right), 6.6$ - 7.1 (m, 4 H, HAr), 9.7 (t, 1 H, HCO).

\section{8-(3-Methoxy)-phenyl-1-(n)-octaloxime (5)}

To a solution of the aldehyde $4(0.89 \mathrm{~g}, 3.81 \mathrm{mmol})$ in ethanol $(15 \mathrm{~mL})$ were added $4.0 \mathrm{~mL}$ each of $5 \mathrm{~mol} \mathrm{~L}^{-1}$ hidroxylamine hydrochloride and $5 \mathrm{~mol} \mathrm{~L}^{-1}$ sodium acetate solution. The resulting mixture was refluxed for a $2 \mathrm{~h}$ interval, during which $2 \mathrm{~mL}$ more of both solutions were added. After cooling, the reaction mixture was extracted with dichloro-methane and the organic extract was washed 0.5 mol L-1 $\mathrm{HCl}$ solution, water and $5 \%$ sodium bicarbonate solution, dried over anhydrous sodium sulfate, filtered and concentrated to give the oxime 5, $0.92 \mathrm{~g}(97 \%)$, as a colorless oil which crystallized upon cooling, with m.p. $58-60^{\circ} \mathrm{C}$; IR $(\mathrm{KBr}) \cup\left(\mathrm{cm}^{-1}\right): 3336-3274,1602,1500,1490,1300 ; \mathrm{MS}(70$ eV) m/z: $249\left(14.9 \%, \mathrm{M}^{+}\right), 232(17.2 \%), 135(20.8 \%), 122$ (100\%), 91 (14.9\%), $77(10.1 \%), 72(25.2 \%), 55(15.3 \%) ;{ }^{1} \mathrm{H}$ $\mathrm{NMR}\left(\mathrm{CDCl}_{3}, 200 \mathrm{MHz}\right) \delta: 1.2-1.6\left(\mathrm{~m}, 10 \mathrm{H}, \mathrm{CH}_{2}\right), 2.2$ (anti) and 2.38 (syn) (q, 2 $\left.\mathrm{H}, \underline{\mathrm{CH}}_{2} \mathrm{CHNOH}\right), 2.58$ (t, $2 \mathrm{H}, \mathrm{CH}_{2} \mathrm{Ar}$ ), 3.79 (s, $3 \mathrm{H}, \mathrm{CH}_{3} \mathrm{O}$ ), 6.7-6.8 (m, 3 H, HAr), 6.7-6.8 (syn) and 7.42 (anti) $(1 \mathrm{H}, \underline{\mathrm{HCNOH}}), 7.19$ (dt, $1 \mathrm{H}, \mathrm{HAr}) ;{ }^{13} \mathrm{CNMR}\left(\mathrm{CDCl}_{3}\right.$, $50.3 \mathrm{MHz}$ ) $\delta$ : 25.91 (syn) and 26.44 (anti), 29.38 (syn) and 25.94 (anti), 28.97, 29.08, 29.22, 31.24, 35.89, 55.02, 110.70, 114.07, 120.77, 129.09, 144.37, 152.76(syn) and 152.17 (anti), 152.41.

\section{8-(3-Methoxy)-phenyl-1-(n)-octylamine hydrochloride (6)}

Oxime 5 ( $0.50 \mathrm{~g}, 2.0 \mathrm{mmol})$ was dissolved in dry ethanol $(50 \mathrm{~mL})$ and chloroform $(3 \mathrm{~mL})$ was added to the solution. The resulting solution was hydrogenated (60 psi) over $\mathrm{PtO}_{2}$ $(0.05 \mathrm{~g})$ for $2 \mathrm{~h}$. The catalyst was then filtered off and the filtrate concentrated. The remaining white solid was washed twice with dry ether to give $0.44 \mathrm{~g}(80 \%)$ of compound 6 as a white solid: m.p. $79-81^{\circ} \mathrm{C}$; IR (KBr) v (cm-1): 3406, 1610, 1582, 1492; MS (70 eV) m/z: 149 (7.8\%), 135 (8.9\%), 122 (56.5\%), 91 (12.3\%), 55 (12.8\%), 36(33.9\%), 30(100\%); ${ }^{1} \mathrm{H}$ $\mathrm{NMR}\left(\mathrm{CDCl}_{3}, 200 \mathrm{MHz}\right) \delta: 1.29\left(\mathrm{br}, 8 \mathrm{H}, \mathrm{CH}_{2}\right), 1.56(\mathrm{br}, 2 \mathrm{H}$, $\mathrm{CH}_{2}$ ), 1.75 (br, 2H, $\mathrm{CH}_{2}$ ), 2.53 (t, 2H, $\mathrm{CH}_{2} \mathrm{Ar}$ ), 2.96 (br, 2H, $\mathrm{CH}_{2} \mathrm{~N}+$ ), 3.76 (s, 3H, $\mathrm{CH}_{3} \mathrm{O}$ ), 6.70-6.75 (m, 3H, HAr), 7.127.24 (br, $1 \mathrm{H}, \mathrm{HAr}), 8.17$ (br, $\left.3 \mathrm{H}, \mathrm{H}_{3} \mathrm{~N}+\right)$; $13 \mathrm{C} \mathrm{NMR}\left(\mathrm{CDCl}_{3}\right.$, $50.3 \mathrm{MHz}) \delta: 26.50,27.53,28.90,29.16,31.25,35.88,39.92$, $54.99,110.72,114.04,120.72,129.07,144.29,159.47$.

8-(3-Methoxy)-phenyl-N,N,N-trimethyl-1-(n)octylammoniun iodide (7)

A mixture of amine hydrochloride $6(0.27 \mathrm{~g}, 1.0 \mathrm{mmol})$, methyl iodide $(0.5 \mathrm{~mL}, 8.0 \mathrm{mmol})$, sodium bicarbonate $(0.38 \mathrm{~g}$, 
$4.0 \mathrm{mmol})$ and dry methanol $(15 \mathrm{~mL})$ was heated under reflux with stirring for $55 \mathrm{~h}$. Additional methyl iodide $(0.2 \mathrm{~mL}, 3.2$ mmol each addition) was added after 24 and $48 \mathrm{~h}$. The reaction mixture was then evaporated under reduced pressure and the residual solid was extracted three times with boiling chloroform. The combined extracts were cooled, filtered and evaporated to dryness. The residue, a colorless soft solid weighting $0.37 \mathrm{~g}(92 \%)$, was identified as the quaternary ammonium salt 7: m.p. $101-102^{\circ} \mathrm{C}$; IR $(\mathrm{KBr}) v\left(\mathrm{~cm}^{-1}\right)$ : 3464 , 1602, 1589, 1486; MS (70eV)m/z: $347(3.1 \%), 277(4.3 \%), 262$ (21.7\%), $142(28.4 \%), 122(62.1 \%), 91(10.8 \%), 77(4.2 \%), 72$ (72.2\%), 58(100\%); ${ }^{1} \mathrm{HNMR}\left(\mathrm{CDCl}_{3}, 200 \mathrm{MHz}\right) \delta: 1.26(\mathrm{br}, 8$ $\left.\mathrm{H}, \mathrm{CH}_{2}\right), 1.50\left(\mathrm{t}, 2 \mathrm{H}, \mathrm{CH}_{2}\right), 1.64\left(\mathrm{br}, 2 \mathrm{H}, \mathrm{CH}_{2}\right), 2.47$ (t, $2 \mathrm{H}$, $\left.\mathrm{CH}_{2} \mathrm{Ar}\right), 3.32\left(\mathrm{~s}, 9 \mathrm{H}, \mathrm{CH}_{3} \mathrm{~N}^{+}\right), 3.50\left(\mathrm{~m}, 2 \mathrm{H}, \mathrm{CH}_{2} \mathrm{~N}^{+}\right), 3.69(3 \mathrm{H}$, $\mathrm{CH}_{3} \mathrm{O}$ ), 6.63-6.69 (m, 3 H, HAr), 7.05-7.13 (m, 1 H, HAr); ${ }^{13} \mathrm{C}$ $\mathrm{NMR}\left(\mathrm{CDCl}_{3}, 50.3 \mathrm{MHz}\right) \delta: 23.03,25.64,28.96,31.13,35.77$, $53.61\left(3 \mathrm{C}, \mathrm{C}_{3} \mathrm{~N}^{+}\right), 55.10,66.88,110.76,113.98,120.72,129.07$, 144.28, 159.36. HRMS (M+ - I) calculated for $\mathrm{C}_{18} \mathrm{H}_{32} \mathrm{NO}^{+}$ 278.2484, found 278.2730.

8-(3-Methoxy)-phenyl-N,N,N-triethyl-1-(n)octylammoniun iodide $(8)$

A mixture of the amine hydrochloride $6(0.27 \mathrm{~g}, 1.0$ $\mathrm{mmol})$, ethyl iodide $(0.6 \mathrm{~mL}, 8.0 \mathrm{mmol})$, sodium bicarbonate $(0.38 \mathrm{~g}, 4.5 \mathrm{mmol})$ and dry methanol $(15 \mathrm{~mL})$ was heated under reflux with stirring for $22 \mathrm{~h}$. Additional ethyl iodide $(0.6 \mathrm{~mL}$ each) was added after 6 and $14 \mathrm{~h}$. The reaction mixture was then evaporated under reduced pressure and the residual solid extracted three times with boiling chloroform. The combined extracts were cooled, filtered and evaporated to dryness. Recrystallization of the residue from ethyl acetate gave $0.37 \mathrm{~g}(83 \%)$ identified as the quaternary ammonium salt 8: m.p. $90-91^{\circ} \mathrm{C}$; IR (KBr) v ( $\left.\mathrm{cm}^{-1}\right)$ : 3448 , 1613, 1582, 1486; ${ }^{1} \mathrm{HNMR}\left(\mathrm{CDCl}_{3}, 200 \mathrm{MHz}\right) \delta: 1.26$ (br, 17 $\mathrm{H}, \mathrm{CH}_{2} \mathrm{eCH}_{3}$ ), 1.53 (br, 4 H, $\mathrm{CH}_{2}$ ), 2.47 (t, 2 H, $\mathrm{CH}_{2} \mathrm{Ar}$ ), 3.15 (t, $\left.2 \mathrm{H}, \mathrm{CH}_{2} \mathrm{~N}+\right), 3.34-3.37\left(\mathrm{~m}, 6 \mathrm{H}, \mathrm{CH}_{2} \mathrm{~N}^{+}\right), 3.69$ (s, $3 \mathrm{H}$, $\mathrm{CH}_{3} \mathrm{O}$ ), 6.63-6.68 (m, $3 \mathrm{H}, \mathrm{HAr}$ ), 7.04-7.25 (m, $1 \mathrm{H}, \mathrm{HAr}$ ); ${ }^{13} \mathrm{C} \mathrm{NMR}\left(\mathrm{CDCl}_{3}, 50.3 \mathrm{MHz}\right) \delta: 8.16 ; 22.00,26.24,29.07$, 31.09,35.76;53.56,55.06,57.51; 110.73, 113.98, 120.71, 129.06, 144.26, 159.36. HRMS (M+ - I) calculated for $\mathrm{C}_{21} \mathrm{H}_{38} \mathrm{NO}^{+}$ 320.2953 , found 320.3990 .

8-(3-Methoxy)-phenyl-N,N,N-tripropyl-1-(n)octylammoniun iodide(9)

A mixture of the amine hydrochloride $6(0.5 \mathrm{~g}, 1.8 \mathrm{mmol})$, propyl iodide $(1.8 \mathrm{~mL}, 16.0 \mathrm{mmol})$, sodium bicarbonate $(0.72$ $\mathrm{g}, 8.5 \mathrm{mmol})$ and dry methanol $(32 \mathrm{~mL})$ was heated under reflux with stirring for $40.5 \mathrm{~h}$. Additional propyl iodide (1.0 $\mathrm{mL}, 8.9 \mathrm{mmol}$ each) was added after 5.5, 11, 17, 24, 29.5 and $37.5 \mathrm{~h}$. The reaction mixture was then evaporated under reduced pressure and the residual solid extracted three times with boiling chloroform. The combined extracts were cooled, filtered and evaporated to dryness. The residue, $0.83 \mathrm{~g}$ (93 $\%$ ) of a yellow viscous liquid was identified as the quaternary ammonium salt 9: IR (film) $v\left(\mathrm{~cm}^{-1}\right)$ : 3440, 1601, 1583, 1486; ${ }^{1} \mathrm{HNMR}\left(\mathrm{CDCl}_{3}, 200 \mathrm{MHz}\right) \delta: 0.98\left(\mathrm{t}, 8 \mathrm{H}, \mathrm{CH}_{2}\right)$, 1.27 (br, $8 \mathrm{H}, \mathrm{CH}_{2} \mathrm{~N}+$ ), 1.67 (br, $\left.10 \mathrm{H}, \mathrm{CH}_{2}\right), 2.49$ (t, $2 \mathrm{H}$, $\left.\mathrm{CH}_{2} \mathrm{Ar}\right), 3.27-3.30\left(\mathrm{~m}, 8 \mathrm{H}, \mathrm{CH}_{2} \mathrm{~N}+\right), 3.72\left(\mathrm{~s}, 3 \mathrm{H}, \mathrm{CH}_{3} \mathrm{O}\right)$, 6.66-6.71 (m, 3 H, HAr), 7.07-7.25 (m, 1 H, HAr); ${ }^{13}$ CNMR $\left(\mathrm{CDCl}_{3}, 50.3 \mathrm{MHz}\right) \delta: 10.86,16.00,22.32,26.28,26.96,29.13$, 31.15, 35.82, 55.09, 60.73, 110.72, 114.02, 120.72, 129.07, 144.27, 159.42. HRMS (M+ - I) calculated for $\mathrm{C}_{24} \mathrm{H}_{44} \mathrm{NO}^{+}$ 362.3423 , found 362.4270 .

\section{Oxidation of cis-cyclooctene (10) with $\mathrm{KMnO}_{4}$}

To a stirred mixture of potassium permanganate $(2.52 \mathrm{~g}$, $16.0 \mathrm{mmol})$ and phase transfer catalyst $7(0.08 \mathrm{~g}, 0.2 \mathrm{mmol})$ in water $(3.0 \mathrm{~mL})$, a solution of cis-cyclooctene $\mathbf{1 0}(0.44 \mathrm{~g}$, $4.0 \mathrm{mmol})$ in benzene $(1.0 \mathrm{~mL})$ was added over $0.5 \mathrm{~h}$ period. The reaction mixture was stirred overnight at room temperature and then the excess permanganate was destroyed with $10 \%$ sodium metabissulfite solution. The product was basified with $\mathrm{NaOH}$ and the benzene solution extracted with ethyl acetate. The aqueous phase was acidified and extracted with ethyl acetate. The combined ethyl acetate extracts were dried over $\mathrm{Na}_{2} \mathrm{SO}_{4}$, filtered and the solvent evaporated to give a white solid residue (0.65 g). After dry flash chromatography (30 g of silica gel, elution with $20 \%$ of ethyl acetate in hexane), $0.53 \mathrm{~g}$ (76\%) of 1,8 octanodioic acid (11) were recovered. The IR and ${ }^{1} \mathrm{H}-\mathrm{NMR}$ spectra of the isolated product were consistent with the assigned structure.

Analogous procedures were carried out using compound $8(0.09 \mathrm{~g}), \mathbf{9}(0.10 \mathrm{~g})$ and Aliquat ${ }^{\circledR}(0.08 \mathrm{~g})$ as phase transfer catalysts, affording 1,8-octanodioic acid (11) in 74\% (0.52 g), $60 \%$ (0.42 g) and 64\% (0.44 g) yields respectively.

\section{Oxidation of benzyl alcohol (12) with $\mathrm{NaClO}$}

To a solution of $12(0.432 \mathrm{~g}, 4.0 \mathrm{mmol})$ and phase transfer catalyst $7(0.08 \mathrm{~g}, 0.2 \mathrm{mmol})$ in dichloromethane $(10 \mathrm{~mL}), \mathrm{a} 4 \%$ sodium hypochlorite solution $(25 \mathrm{~mL})$ was added. The mixture was stirred at room temperature for $6 \mathrm{~h}$, then extracted with dichloromethane, dried over $\mathrm{Na}_{2} \mathrm{SO}_{4}$, and filtered. The solvent was evaporated to yield $0.28 \mathrm{~g}(67 \%)$ of a yellow liquid residue identified as benzaldehyde (13), by comparison of the IR and ${ }^{1} \mathrm{H}-\mathrm{NMR}$ spectra with those of an authentic sample.

Identical procedures, performed with phase transfer catalysts $8(0.08 \mathrm{~g}), \mathbf{9}(0.10 \mathrm{~g})$ and $\operatorname{Aliquat}^{\circledR}(0.08 \mathrm{~g})$, gave aldehyde 13 in $27 \%$ (0.12 g), 26\% (0.11 g) and 49\% (0.21 g) yields, respectively. 
Williamson synthesis of benzyl ether(15)

To a mixture of benzyl alcohol $12(0.54 \mathrm{~g}, 5.0 \mathrm{mmol})$ and compound 7 ( $0.10 \mathrm{~g}, 0.3 \mathrm{mmol})$, benzyl chloride 14 (1.2 mL, $10 \mathrm{mmol}$ ) and a $50 \%$ sodium hydroxide solution $(5.4 \mathrm{~mL})$ were added. The reaction mixture was stirred at room temperature overnight. The reaction products were then extracted with ethyl acetate and the organic extracts were dried $\left(\mathrm{Na}_{2} \mathrm{SO}_{4}\right)$, filtered and evaporated. The residue, a yellow liquid, was distilled under reduced pressure $(1 \mathrm{mmHg})$ affording $0.75 \mathrm{~g}(76 \%)$ of compound 15 , which was identified by IR and ${ }^{1} \mathrm{H}-\mathrm{NMR}$ spectroscopy.

Same procedure was repeated three times, using compounds $8(0.10 \mathrm{~g}), 9(0.12 \mathrm{~g})$ and Aliquat ${ }^{\circledR}(0.10 \mathrm{~g})$ as phase transfer catalysts. Yields of 15 were $98 \%$ (0.97 g), $84 \%(0.83 \mathrm{~g})$ and $60 \%(0.59 \mathrm{~g})$ respectively.

\section{Acknowledgments}

The authors were grateful to Professor Raimundo Braz Filho for the acquisition and interpretation of some ${ }^{1} \mathrm{H}$ and ${ }^{13}$ C NMR (200 and 50,3 MHz) spectra. We thank Dr. C. Bloch Júnior (Cenargen-Embrapa) for the HRMS. This work was partially supported by CNPq and PADCT (FINEP). One of us, G.C.M., also thanks CNPq for the award of a fellowship.

\section{References}

1. Johnson, D. V. O Caju do Nordeste do Brasil - Um
Estudo Geográfico, ETENE/BNB, Fortaleza, Brasil, 1974.

2. Anand, L. C. Popular Plastics 1978, 15.

3. (a) Carvalho, M. G.; Braz-Filho, R.; Santos, M. L.; Magalhães, G. C. J. Braz. Chem. Soc. 1993, 4, 158. (b) Santos, M. L.; Magalhães, G. C. Quím. Nova 1993, 16, 534. (c) Santos, M. L.; Magalhães, G. C.; BrazFilho, R. J. Organomet. Chem. 1996, 15, 526. (d) Santos, M. L. Ph.D. Thesis, Departamento de Química, Universidade de Brasília, 1997.

4. Domagk, G. Dtsch. Med. Wschr. 1935, 61, 829.

5. Gulati, A. S.; Krishnamachar, V. C.; Subba Rao, B. C. Indian J. Chem. 1964, 2, 114.

6. Mcintosh, J. M. J. Chem. Educ. 1978, 55, 237.

7. Lee, G. A.; Freedman, H. H. Tetrahedron Lett.1976, 1641.

8. Freedman, H. H.; Dubois, R. A. Tetrahedron Lett. $\mathbf{1 9 7 5}, 38,3251$.

9. Symes, W.; Dawason, C. J. Am. Chem. Soc. 1953, 75,4952 .

10. Ericson, R. E.; Bailey, P. S. Org. Synth. 1973, Coll. Vol. V, 489.

11. Fieser, L. F. Experiments in Organic Chemistry, 3rd ed., D. C., Heath and Company, Boston, USA, 1955, p. 103.

12. Secrist III, J.; Logne, M. J. Org. Chem. 1972, 37, 335.

13. Cope, A.; Ciganek, E.; Fleckenstein, L.; Meisinger, M. J. Am. Chem. Soc. 1960, 82, 4651.

14. Durrani, A. A.; Davis, G. L.; Sood, S. K.; Tychopoulos, V.; Tyman, J. H. P. J. Chem. Technol. Biotechnol.1982, 32,618 . 